\title{
PENERAPAN STRATEGI ACTIVE LEARNING TIPE KONTRAK BELAJAR DALAM KEGIATAN MENULIS ARTIKEL
}

\author{
Alfa Mitri Suhara ${ }^{1}$, Diena San Fauziya ${ }^{2}$ \\ Program Studi Bahasa dan Sastra Indonesia STKIP Siliwangi Bandung \\ Email: alfa.mitri@gmail.com
}

\begin{abstract}
Abstrak
Penelitian ini dilatarbelakangi oleh adanya masalah dalam kegiatan menulis, mulai dari kelebihan atau kekurangan ide, sibuk, ataupun malas. Untuk mengatasi masalah tersebut, dimunculkan model pembelajaran active learning tipe kontrak belajar sebagai solusi yang diyakini efektif digunakan. Masalah yang hendak dipecahkan adalah bagaimana kemampuan sebelum dan setelah serta pelaksanaan pembelajaran menulis artikel dengan model cooperative learning tipe kontrak belajar. Tujuan penelitian adalah untuk melihat efektivitas model cooperative learning tipe kontrak belajar dalam menulis artikel. Metode penelitian yang digunakan untuk memecahkan masalah adalah metode eksperimen. Yang menjadi sampel penelitian adalah mahasiswa PBS. Indonesia STKIP Siliwangi angkatan 2014. Berdasarkan hasil penelitian, diperoleh simpulan bahwa terdapat perbedaan yang signifikan antara pretes dan postes pada mahasiswa semester 3 angkatan 2014 dalam pembelajaran menulis artikel dengan menggunakan strategi active learning tipe kontrak belajar. Hal ini dibuktikan t dari hasil perhitungan kuadrat deviasi, koefisien, uji $\mathrm{t}$, dan analisis yang telah dilakukan diperoleh hasil derajat kebebasan sebesar 34 dengan tingkat kepercayaan $95 \%$ ternyata $t_{\text {hitung }}>t_{\text {tabel }}$, yakni 2,75 $>2,04$.
\end{abstract}

Kata kunci: strategi active learning, kontrak belajar, menulis, artikel

\begin{abstract}
This research is conducted by the proportions of writing activities, such as excess or shortage of ideas, busy, or lazy. To overcome these problems, it raised active learning contract type as the learning model to be a solution that believed will be effectively used. The problem will be solved is how the writing ability before and after and during the process of the implementation of writing articles with the contract type cooperative learning models. The purpose of this research is to find the effectiveness of contract type cooperative learning models in writing articles. The method used to solve the problems is the experimental method. The samples are the PBS students of STKIP Siliwangi 2014. Based on the results, it concluded that there are significant differences between pretest and posttest in semester 3 years 2014 students in writing articles using active strategies contract type cooperative learning models. This is evidenced by t from the calculation of the squared deviations, coefficients, $t$-test, and analysis has been done shows degrees of freedom at 34 with $95 \%$ level of confidence turned out to $t_{\text {hitung }}>t_{\text {tabel }}$, specifically $2,75>2,04$.
\end{abstract}

Keywords: active learning strategy, learning contracts, and writing, article

\section{PENDAHULUAN}

Menulis merupakan keterampilan yang penting dimiliki oleh mahasiswa. Hal ini sekaitan dengan tugas dan fungsi mahasiswa sebagai calon akademisi. Kemampuan menulis bagi mahasiswa sangat penting dan menunjang dalam penyelesaian tugas-tugas kuliah bahkan se- 
telah mahasiswa memasuki dunia kerja. Bukan hanya itu saja, produktivitas menulis merupakan salah satu indikator berkembangnya pikiran seseorang, baik secara imajinatif maupun secara kritis. Dengan demikian, keterampilan menulis menjadi hal yang penting dimiliki oleh mahasiswa sebagai orang yang berpikiran tinggi. Selain itu, kemampuan menulis dalam konteks luas sangat penting untuk perkembangan pengetahuan dan teknologi. Menurut Cahyani (2006:3) mengungkapkan bahwa pengeembangan iptek memerlukan komunikasi dalam bentuk bahasa tulis yang efektif.

Menulis yang dapat meningkatkan dan mengembangkan keterampilan menulis mahasiswa adalah menulis artikel. Artikel merupakan tulisan lepas berisi opini seseorang yang mengupas dengan tuntas suatu masalah tertentu yang bersifat aktual, kontroversial dengan tujuan persuasif dan menghibur pembaca, misalnya laporan berita atau esai di majalah, surat kabar, dan sebagainya. Namun, kegiatan menulis artikel masih jarang dilakukan oleh mahasiswa. Hal ini dipengaruhi oleh kurangnya kemampuan menulis yang dimiliki oleh mahasiswa. Ketika menulis mahasiswa kesulitan untuk mengembangkan topik, memilih diksi, dan membuat kalimat sehingga membuat mahasiswa malas dan bosan untuk menulis. Berdasarkan pengalaman tersebut membuat mahasiswa melakukan kegiatan menulis karena terpaksa. Beberapa kendala dalam kegiatan menulis diungkap pula oleh Zainurrahman (2011:217221) bahwa kendala khusus menulis hilangnya mood untuk menulis, kekurangan atau kehabisan ide, kesibukan, fluktuasi psikologis.

Berdasarkan permasalahan yang yang telah dikemukakan di atas, maka perlu ditemukan sebuah strategi pembelajaran yang tepat dan dapat mendorong minat mahasiswa untuk meningkatkan kemampuan menulis, khususnya menulis artikel. Selain itu, dibutuhkan juga cara belajar yang tepat dan menarik sehingga memberikan perubahan terhadap kemampuan menulis mahasiswa. Strategi pembelajaran yang digunakan juga harus dapat membawa perubahan dan pembaharuan dalam proses pembelajaran. Strategi pembelajaran yang dapat digunakan oleh dosen untuk mengatasi permasalahan tersebut dengan menerapkan strategi active learning tipe kontrak belajar. Strategi pembelajaran active learning tipe kontrak belajar merupakan rancangan pembelajaran yang menimbulkan kesadaran akan perasaan, nilai-nilai, dan sikap untuk melakukan kegiatan menulis. Strategi belajar ini efektif untuk menumbuhkan kesadaran dalam diri mahasiswa bahwa menulis artikel adalah sebuah kebutuhan dan sesuatu yang mengasyikkan karena dapat mengembangkan pikiran, kreativitas, dan kedisiplinan.

Berdasarkan batasan masalah yang telah diuraikan di atas, maka rumusan masalah yang hendak dipecahkan dalam penelitian ini: pertama bagaimana kemampuan menulis artikel pada mahasiswa Program Studi Pendidikan Bahasa dan Sastra Indonesia STKIP Siliwangi Bandung sebelum menggunakan strategi pembelajaran active learning tipe kontrak belajar?; kedua bagaimana pelaksanaan penerapan strategi pembelajaran active learning tipe kontrak belajar dalam pembelajaran menulis artikel pada mahasiswa Program Studi Pendidikan Bahasa dan Sastra Indonesia STKIP Siliwangi Bandung? ketiga bagaimana kemampuan menulis artikel pada mahasiswa Program Studi Pendidikan Bahasa dan Sastra Indo- 
nesia STKIP Siliwangi Bandung setelah menggunakan strategi pembelajaran $a c$ tive learning tipe kontrak belajar? empat apakah terdapat perbedaan yang signifikan antara kemampuan menulis artikel pada mahasiswa Program Studi Pendidikan Bahasa dan Sastra Indonesia STKIP Siliwangi Bandung sebelum dan setelah menggunakan strategi pembelajaran $a c$ tive learning tipe kontrak belajar?

\section{KAJIAN TEORITIS A. Kontrak Belajar}

Strategi Kontrak Belajar merupakan salah satu strategi dari pendekatan Active Learning yang memberikan kebebasan kepada mahasiswa untuk menentukan sendiri apa yang hendak dipelajarinya. Silberman (2011:207) mengungkapkan bahwa belajar yang timbul dari keinginan sendiri acapkali lebih mendalam dan lebih permanen ketimbang belajar yang diarahkan oleh Dosen. Meskipun demikian, ia menyatakan bahwa Dosen tetap memastikan bahwa kesetujuan terhadap apa dan bagaimana sesuatu akan dipelajari haruslah jelas. Melalui strategi Kontrak Belajar, pada awal pem-belajaran mahasiswa terlebih dahulu me-rumuskan tujuan belajar, kegiatan belajar, bukti tujuan telah tercapai, serta waktu penyelesaian.

Active Learning sendiri merupakan kegiatan belajar aktif yang bisa membuahkan hasil belajar yang langgeng (Silberman, 2011:9). Menurutnya, agar belajar menjadi aktif, mahasiswa harus mengerjakan banyak sekali tugas. Mereka harus menggunakan otak, mengkaji gagasan, memecahkan masalah, dan menerapkan apa yang mereka pelajari.

\section{B. Pembelajaran}

Pembelajaran adalah proses interaksi peserta didik dengan pendidik dan sumber belajar pada suatu lingkungan belajar yang didalamnya terjadi proses pemerolehan ilmu dan pengetahuan, penguasaan kemahiran dan karakter, serta pembentukan sikap dan kepercayaan pada peserta didik. Dalam Undang-Undang No. 20 Tahun 2003 Tentang Sistem Pendidikan Nasional pasal 1 ayat 20 dinyatakan bahwa Pembelajaran 11 adalah Proses interaksi peserta didik dengan pendidik dan sumber belajar pada suatu lingkungan belajar. Menurut Dimyati dan Mudjiono dalam Sagala, (2011: 62), pembelajaran adalah kegiatan guru secara terprogram dalam desain instruksional, untuk membuat belajar secara aktif, yang menekankan pada penyediaan sumber belajar.

Lebih lanjut, Corey dalam Sagala (2011: 61), konsep pembelajaran adalah suatu proses dimana lingkungan seseorang secara disengaja dikelola untuk memungkinkan ia turut serta dalam tingkah laku tertentu dalam kondisi-kondisi khusus atau menghasilkan respons terhadap situasi tertentu, pembelajaran merupakan subset khusus dari pendidikan. Pembelajaran mengandung arti setiap kegiatan yang dirancang untuk membantu seseorang mempelajari suatu kemampuan dan nilai yang baru. Proses pembelajaran pada awalnya meminta guru untuk mengetahui kemampuan dasar yang dimiliki oleh siswa meliputi kemampuan dasarnya, motivasinya, latar belakang akademisnya, latar belakang ekonominya, dan lain sebagainya. Kesiapan guru untuk mengenal karakteristik siswa dalam pembelajaran merupakan modal utama penyampaian bahan belajar 
dan menjadi indikator suksesnya pelaksanaan pembelajaran.

Berdasarkan penjelasan di atas dapat kita diketahui bahwa pembelajaran adalah usaha yang dilakukan oleh guru kepada siswa untuk melakukan kegiatan belajar dengan melakukan interaksi secara langsung dimana didalamnya terjadinya perubahan tingkah laku pada diri siswa yang belajar dalam waktu yang relatif lama.

\section{Tujuan Pembelajaran}

Tujuan pembelajaran merupakan harapan, yaitu apa yang diharapkan dari siswa sebagai hasil belajar. Menurut Robert F. Meager (Sumiati dan Asra, 2009: 10) memberi batasan yang lebih jelas tentang tujuan pembelajaran, yaitu maksud yang dikomunikasikan melalui peenyataan yang menggambarkan tentang perubahan yang diharapkan dari siswa. Menurut Daryanto (2005: 58), tujuan pembelajaran adalah tujuan yang menggambarkan pengetahuan, kemampuan, keterampilan, dan sikap yang harus dimiliki siswa sebagai akibat dari hasil pembelajaran yang dinyatakan dalam bentuk tingkah laku yang dapat diamati dan diukur. Lebih lanjut Suryosubroto (1990: 23) menegaskan bahwa tujuan pembelajaran adalah rumusan secara terperinci apa saja yang harus dikuasai oleh siswa sesudah ia melewati kegiatan pembelajaran yang bersangkutan dengan berhasil.

Tujuan pembelajaran memang perlu dirumuskan dengan jelas, karena perumusan tujuan yang jelas dapat digunakan sebagai tolak ukur keberhasilan dari proses pembelajaran itu sendiri. Tujuan pembelajaran tercantum dalam rencana pelaksanaan pembelajaran (RPP). RPP merupakan komponen penting dalam ku- rikulum tingkat satuan pendidikan yang pengembangannya harus dilakukan secara profesional.

\section{Karakteristik Pembelajaran}

Pembelajaran memiliki karakteristik yang khas sehingga memiliki cirri tersendiri dalam pelaksanaan kegiatannya. Adapun ciri khas dalam kegiatan pembelajaran menurut Hamalik (1995: 66), sebagai berikut.

1. Rencana ialah penataan ketenagaan, material, dan prosedur yang merupakan unsur-unsur sistem pembelajaran dalam suatu rencana khusus.

2. Kesalingtergantungan (interdepence), antara unsur "sistem pembelajaran yang serasi dalam suatu keseluruhan". Tiap unsur bersifat esensial, dan masing masing memberikan sumbangannya kepada sistem pembelajaran.

3. Tujuan, sistem pembelajaran mempunyai tujuan tertentu yang hendak dicapai. Seperti sistem transportasi, sistem komunikasi, sistem pemerintahan, semuanya memiliki tujuan.

\section{E. Menulis}

Kegiatan menulis bisa dimulai dengan menulis catatan harian. Hal demikian ditegaskan Alwasilah (2007:5) bahwa keterampikan menulis diawali dengan penggunaan bahasa secara ekspresif dan imajinatif seperti melalui catatan harian. Dalam catatan harian, seseorang mengekspresikan ranah afektifnya secara ekspresif dan juga imajinatif, bukan dimulai dengan pemahaman kognitif.

Menulis merupakan kegiatan yang kompleks karena melibatkan unsur kebahasaan dan unsur di luar bahasa yang akan menjadi isi tulisan. Unsur-unsur tersebut akan menghasilkan tulisan yang runtut dan padu. Agar komunikasi lewat 
lambang tulis berjalan dengan lancar seperti yang diharapkan, penulis harus mampu menuangkan gagasannya ke dalam bahasa yang tepat, teratur dan lengkap.

Istilah menulis di masyarakat disamakan dengan mengarang. Namun tidak semua orang menyetujuinya. Menurut Nurudin (2010:2), mengarang umumnya lekat dengan sebuah tulisan yang berkaitan dengan fiksi sedangkan menulis bersifat netral. Dalam KBBI (1990:968) disebutkan bahwa menulis adalah membuat huruf (angka dan sebagainya) dengan pena (pensil, kapur, dsb); melahirkan pikiran atau perasaan (seperti mengarang, membuat surat) dengan tulisan, menggambar, melukis, membatik kain. dalam kaitannya dengan penelitian ini, pengertian menulis yang kedua yang digunakan, karena menulis dalam penelitian ini dimaksudkan sebagai suatu kegiatan mengungkapkan ide, gagasan, dan perasaan dalam bahasa tulis.

Secara sederhana Miller (Hughey, et.al., 1983:10) mengungkapkan bahwa "writing, like life itself, is a voyage of discovery" (menulis seperti kehidupan itu sendiri yang ditemukan melalui sebuah perjalanan). Pendapat Miller tersebut kemudian diperluas oleh Hughey, et.al. (1983:25) yang mengatakan bahwa melalui tulisan kita dapat mengungkapkan perasaan, harapan, mimpi, dan sukacita kita. Melalui menulis kita juga dapat mengekspresikan ide, rencana, rekomendasi, nilai, dan komitmen kita. Selain itu, kita juga dapat menjelaskan kepada orang lain apa yang kita percayai, pahami, dan alasan mengapa kita percaya dan memahami hal tersebut (through writing we express our feelings - our hopes, dreams, and joys .... Through writing we express our ideas-our plans, our recommendations, our values, and our commitments. We explain to others who we are, what we believe, and understand, and why we believe and understand as we do).

Menurut Hirsch (Hughey, et.al., 1983: 3) bahwa "writing is for more than a way of recording language by means of visible marks". Artinya menulis lebih ke arah proses perekaman tanda-tanda bahasa yang bisa dilihat atau berbentuk nyata.

Tarigan (2008:3-4) menyimpulkan bahwa menulis merupakan suatu keterampilan berbahasa yang dipergunakan untuk berkomunikasi secara tidak langsung, tidak secara tatap muka dengan orang lain. Menulis merupakan suatu kegiatan yang produktif dan ekspresif. Dalam kegiatan ini penulis haruslah terampil memanfaatkan grafolegi, struktur bahasa, dan kosa kata. Tarigan juga menjelaskan bahwa menulis merupakan kegiatan menurunkan lambang-lambang grafik yang menggambarkan suatu bahasa yang dipahami bersama. Hal senada disampaikan oleh Akhadiah, dkk (1988:2), memaknai menulis sebagai suatu kegiatan mengorganisasikan gagasan secara sistematik serta mengungkapkan secara tersurat.

Berdasarkan pendapat di atas, dapat disimpulkan bahwa menulis adalah salah satu keterampilan bahasa yang produktif dan ekspresif. Melalui kegiatan menulis seseorang dapat meng-ungkapkan ide dan perasaan melaui tulisan dengan menggunakan huruf-huruf atau angka-angka.

\section{F. Tujuan Menulis}

Menulis sangat penting bagi pendidikan karena memudahkan para pelajar berpikir. Sama dengan keterampilan berbahasa yang lain, menulis merupakan salah satu cara berkomunikasi 
yang memiliki banyak tujuan. Diantaranya dengan menguasai keterampilan menulis diharapkan siswa dapat mengungkapkan gagasan, pikiran dalam berbagai jenis tulisan baik yang berbentuk fiksi maupun nonfiksi. Menurut D'Angelo dalam Tarigan (2008:25), membagi tujuan penulisan suatu tulisan sebagai berikut.

1. Tujuan penugasan (Assigment Purpo$s e$ ), menulis karena ditugaskan bukan atas kemauan sendiri. Tujuan penugasan ini sebenarnya tidak memiliki tujuan sama sekali. Seseorang menulis karena ditugaskan bukan atas kehendak sendiri (misalnya seorang siswa yang diberikan tugas untuk merangkum atau seorang sekretaris yang ditugaskan untuk menulis laporan atau notulen rapat).

2. Tujuan Menyenangkan (Altruistic Purpose), menulis untuk menyenangkan pembaca, memahami dan menghargai perasaan dan penalarannya, ingin membuat hidup pembaca lebih muda serta menyenangkan dengan karyanya itu.

3. Tujuan Meyakinkan (Persuasive Purpose), meyakinkan para pembaca akan kebenaran gagasan yang diutarakan.

4. Tujuan Informasional, tujuan penerangan (Information Purpose), tulisan yang bertujuan memberikan informasi atau penerangan kepada pembaca.

5. Tujuan Pernyataan Diri (Self Expressive Purpose), tulisan yang bertujuan memperkenalkan atau menyatakan diri sang pengarang kepada para pembaca.
6. Tujuan Kreatif (Creative Purpose), tulisan yang bertujuan mencapai nilai- nilai artistik, nilai-nilai kesenian.

7. Tujuan Pemecahan Masalah (Problem Solving Purpose), bertujuan untuk memecahkan masalah.

Sejalan dengan pendapat Tarigan mengenai tujuan menulis, Reinking (1999:4-5) mengemukakan tujuan menulis secara umum. Tiga tujuan tersebut adalah sebagai berikut.

1. Tujuan Menulis untuk Menginformasikan

Secara umum seseorang dalam menulis adalah menyajikan informasi kepada orang lain. Contohnya seorang pembaca berita di televisi menyajikan berita hasil liputan wartawan kepada penonton di rumah.

2. Tujuan Menulis untuk Meyakinkan Seseorang yang memiliki pandangan yang tajam mengenai suatu persoalan kemudian mengemukakan hal tersebut kepada pembaca melalui media massa. Ia mengirimkan artikel yang isinya menentang kebijakan pemerintah mengenai kenaikan harga minyak besubsidi. Biasanya kebijakan pemerintah yang tidak tepat akan menimbulkan reaksi sebagian orang sehingga menulis tulisan yang bernada mengkritik atau mengusulkan perubahan.

3. Tujuan Menulis untuk Menghibur Beberapa orang menuangkan gagasan atau pikirannya ke dalam bentuk tulisan dengan maksud untuk menghibur. Mereka membuat tulisan dengan materi menyenangkan sehingga pembaca tidak bosan dan merasa terhibur.

Dari beberapa pandangan di atas dapat disimpulan bahwa menulis bukan sekadar kegiatan biasa. Menulis secara 
umum menyajikan informasi, menghibur, meyakinkan dan secara khusus memengaruhi pembaca. Dengan demikian menulis merupakan wujud komunikasi yang efektif dan efisien antara penulis dengan pembaca.

\section{G. Manfaat Menulis}

Manfaat dari menulis dapat mengasah otak kiri seseorang yang berkaitan dengan analisis dan rasional. Karena saat kegiatan menulis berlangsung, secara tidak langsung melatih dan memberikan kebebasan kepada otak untuk mencipta, mengintuisi, dan merasakan dan dituangkan dalam sebuah tulisan. Adapun manfaat menulis menurut Burudin (2010:2025) sebagai berikut.

1. Sarana mengungkapkan perasaan hati (kegelisahan, keinginan, kemarahan). Sebagian orang lebih mampu mengungkapkan isi hatinya dengan menulis daripada lisan.

2. Untuk menancapkan pemahaman ke dalam otak penulis. Meski disadari bahwa pikiran manusia ada batasnya, menulis adalah bentuk kepekaan kita sebagai manusia akan kelemahan dirinya. Para pembicara yang ngin tampil dalam sebuah acara misalnya melakukan pembuatan makalah untuk menguatkan ingatan akan sesuatu yang ingin disampaikan di forum.

3. Membantu mengembangkan kepuasan pribadi, kebanggaan, perasaan harga diri. Dengan menulis kepercayaan diri seseorang menjadi bertambah.

4. Meningkatkan kesadaran dan penyerapan terhadap lingkungan. Seyogyanya menulis menuntut orang untuk terus belajar. Terhadap masalah sosial, seorang penulis diasah kepekaan indrawinya dan mampu me- ngembangkan sikap peduli terhadap orang lain yang menderita.

5. Menulis membiasakan sesorang untuk mencipta. Karena menulis akan membiasakan diri menjadi kreatif, inovatif, dan peduli dengan masalah lingkungan. Jika ada sesuatu yang menurut penulis tidak baik atau kurang pas, dia akan terpanggil untuk mengomentari lewat tulisan-tulisannya.

Pendapat senada diungkapkan oleh Suparno (200:14) bahwa menulis memberikan manfaat yakni peningkatan kecerdasan, pengembangan daya kreativitas, penumbuhan keberanian, dan pendorong kemauan dan kemampuan mengumpulkan informasi. Berdasarkan beberapa pendapat di atas penulis menyimpulkan bahwa menulis dapat melatih seseorang menjadi kreatif, memecahkan masalah, membiasakan seseorang untuk peduli pada lingkungan sosial.

\section{H. Tahapan Menulis}

Menulis merupakan salah satu alat untuk berkomunikasi dalam kehidupan sehari-hari yang bertujuan menyampaikan informasi. Untuk menyampaikan informasi dengan jelas dan tepat, maka diperlukan tahapan menulis yang baik. Adapun tahapan menulis menurut Tompkins (Sukino, 1991:21-30) adalah sebagai berikut.

1. Prapenulisan (Prewriting)

Tahap ini dimulai dengan penentuan topik. Topik yang ditetapkan sebaiknya memenuhi asas kebermanfaatan. menarik, dan visibilitas. Langkah selanjutnya membatasi topik. Hal ini dimaksud menghindari penulis dari rasa bingung karena luasnua topik yang dipilih. Dengan membatasi topik sebenarnya penulis telah menemukan tujuan penulisan. Berikutnya yang perlu dilakukan penulis ada- 
lah mengumpulkan data dan pengorganisasian ide. Bahan informasi biasa diperoleh melalui pengalaman dan sumber pustaka. Setelah itu langkah yang dilakukan adalah menyusun kerangka karangan. Kerangka yang baik harus logis, sistematis dan konsisten.

2. Tahap Penulisan

Pada tahap ini ditandai dnegan penulis menuangkan idenya secara langsung dalam bentuk tulisan dan itu bisa berdasarkan kerangka karangannya.

3. Tahap Revisi

Jika draft tulisan selesai, tulisan tersebut perlu dibaca kembali. Mungkin draft perlu ditambah, dikurangi, atau diperluas. Hal ini yang dilakukan pada tahap revisi. Pada tahap revisi fokus lebih kepada isi tulisan. Revisi seyogyanya menurut Mayer (Santrock, 2007:432) merupakan komponen utama dari penulisan yang sukses. Revisi melibatkan pendeteksian dan pengoreksian kesalahan. Menurut Bartlett (Santrock, 2007:433) bahwa semakin dewasa dan semakin ahli si penulis, semakin mungkin ia merevisi tulisan mereka ketimbang penulis muda yang belum berpengalaman. Berdasarkan hal tersebut dapat disimpulkan bahwa tahap revisi memiliki peran penting untuk menghasilkan sebuah tulisan yang baik.

4. Tahap Editing

Tahap ini lebih difokuskan pada maalaj mekanik seperti ejaaan, penggalan kata, kata penghubung, struktur kalimat dalam tulisan. Editing dilakukan agar tulisan memiliki keterbacaan yang baik. Dengan demikian pembaca mudah memahami isi tulisan.

5. Tahap Publikasi

Tahap terakhir dalam proses penulisan adalah tahap publikasi. Publikasi yang dimaksud dapat dimaknai sebagai proses mengomunikasikan tulisan kepada pembaca atau orang lain.

\section{Artikel}

Artikel adalah tulisan lepas berisi opini seseorang yang mengupas tuntas suatu masalah tertentu yang sifatnya aktual dan kadang-kadang kontroversial dengan tujuan untuk memberi tahu (informatif), mempengaruhi, meyakinkan (persuasif argumentatif), dan menghibur khalayak pembaca (Sumadiria, 2004:1). Menurut Kamus Besar Bahasa Indonesia (KBBI, 2001:66), artikel adalah karya tulis lengkap, misalnya laporan berita atau esai di majalah, surat kabar, dan sebagainya.

\section{J. Kriteria Menulis Artikel}

Berdasarkan beberapa sumber ada beberapa hal yang harus diperhatikan dalam menulis artikel, diantaranya sebagai berikut.

1. Artikel harus asli (bukan plagiat) dan bukan sekedar kompilasi

2. Artikel mengandung unsur baru

3. Uraian yang disajikan membuka pemahaman baru

4. Subtansi yang diulas luas menyangkut kepentingan umum

5. Menggunakan bahasa populer

6. Panjang artikel mulai dari 500 kata sama dengan 4.500 karakter, 600 kata sama dengan 5.000 karakter, hingga 700 kata sama dengan 5.300 karakter.

\section{METODE PENELITIAN}

Penelitian yang akan dilakukan ini merupakan sebuah penelitian kuantitatif dengan metode eksperimen. Metode penelitian ini ditetapkan sesuai dengan rumusan masalah dan tujuan yang telah ditetapkan, yakni untuk melihat apakah 
ada perbedaan yang signifikan antara kemampuan mahasiswa dalam menulis artikel sebelum dan sesudah penerapan strategi pembelajaran active learning tipe kontrak belajar. Berdasarkan rumusan masalah yang telah dipaparkan pada bab sebelumnya, maka rancangan penelitian yang dipilih adalah eksperimen tipe One Group Pretest-Posttest Design dengan

\begin{tabular}{|lll|}
\hline $\mathbf{O}_{1}$ & $\mathbf{X}$ & $\mathbf{O}_{2}$ \\
\hline
\end{tabular}

ilustrasi sebagai berikut.

Keterangan:

$\mathrm{O}_{1} \quad=$ Hasil Tes Awal

$\mathrm{O}_{2} \quad=$ Hasil Tes Akhir

$\mathrm{X}=$ Perlakuan

\section{A. Tahapan Perencanaan Penelitian}

Adapun tahapan perencanaan dalam penelitian ini sebagai berikut:

1. Merumuskan tujuan penelitian

2. Menentukan unit studi dan menghubungkan hal yang akan dikaji berdasarkan sifat-sifat yang dimiliki dan proses yang menjadi landasan penelitian

3. Menentukan rancangan dalam memilih unit dan teknik pengumpulan data

4. Mengumpulkan data

5. Mengorganisasikan informasi, data yang terkumpul, serta melakukan interpretasi dan generalisasi

6. Menyusun laporan yang diakhiri dengan menyimpulkan hasil penelitian.

\section{B. Lokasi Penelitian}

Penelitian dilaksanakan di STKIP Siliwangi Bandung Jl. Terusan Jenderal Soederman Kebon Rumput, Cimahi.

\section{Variabel Penelitian}

Variabel dalam penelitian ini terdiri atas variabel bebas dan terikat. Variabel bebas dalam penelitian adalah strategipembelajaran active learning tipe kontrak belajar sedangkan variabel terikat adalah pembelajaran menulis artikel.

\section{Populasi dan Sampel}

Populasi dalam penelitian ini adalah mahasiswa tingkat II angkatan 2014 STKIP Siliwangi Bandung yang berjumlah sekitar 120 orang. Sampel yang direncanakan berjumlah 40 orang. Pengambilan sampel dilakukan dengan menggunakan teknik purposive sampling.

\section{E. Teknik Pengumpulan Data Penelitian}

Teknik pengumpulan data pada penelitian ini mengacu pada penelitian kualitatif. Adapun tekinik pengumpulan data yang digunakan dalam penelitian ini adalah observasi dan tes.

\section{Observasi}

Observasi dibuat untuk melakukan pengamatan langsung terhadap objek atau situasi yang diteliti. Dalam hal ini pengamatan langsung terhadap berbagai kejadian atau situasi nyata di kelas, sehingga melalui teknik ini peneliti dapat merekam atau mencatat secara teliti dan utuh peristiwa dalam situasi yang berkaitan dengan penelitian. Observasi dalam penelitian ini dilakukan untuk mengamati aktivitas yang terkait dengan pelaksanaan pendekataan kontekstual dalam pembelajaran menulis artikel.

Secara khusus, observasi ini dilakukan untuk mencermati beberapa hal yang berkaitan dengan proses belajar mengajar dengan penerapan kontrak belajar dalam pembelajaran menulis artikel pada mahasiswa Program Studi Pendidikan Bahasa dan Sastra Indonesia STKIP Siliwangi Bandung, antara lain: (1) kegiatan 
pengajaran dari mulai pembukaan, kegiatan inti, dan akhir pengajaran dengan menggunakan strategiactive learning tipe kontrak belajar, (2) aktivitas berinteraksi proses belajar mengajar antara Dosen dengan mahasiswa, antara mahasiswa, serta partisipasi mahasiswa dalam pembelajaran, dan (3) penerapan menggunakan strategiactive learning tipe kontrak belajar dalam proses belajar mengajar.

\section{Tes}

Tes pada umumnya digunakan untuk menilai dan mengukur hasil belajar mahasiswa, terutama hasil belajar yang berkenaan dengan penguasaan bahan pengajaran serta tujuan pengajaran. Tes ini dilakukan penulis untuk memperoleh data dan informasi tentang prestasi hasil belajar mahasiswa pada pokok bahasan tertentu dalam kegiatan belajar mengajar.

Bentuk tes yang digunakan adalah bentuk tes uraian, yaitu bentuk tes yang terdiri atas pertanyaan atau suruhan yaitu menulis artikel. Tes dilakukan dalam bentuk tes awal dan tes akhir. Tes awal digunakan untuk mengukur kemampuan menulis mahasiswa sebelum diberikan pembelajaran (perlakuan), dan tes terakhir digunakan untuk mengukur keberhasilan mahasiswa setelah diberikan pembelajaran menulis artikel dengan menggunakan strategi active learning tipe kontrak belajar.

Pengumpulan data dilakukan oleh peneliti dan dibantu oleh dosen mata kuliah sebagai dosen strategi. Strategi pembelajaran menggunakan active learning tipe kontrak belajar dalam pembelajaran menulis artikel mulai dari tes awal, tiap siklus pembelajaran, dan tes akhir. Dalam penelitian ini, menggunakan teknik-teknik yang merupakan rangkaian proses berupa langkah-langkah yang sesuai dengan rencana dan sistematika untuk mendapatkan data dalam memecahkan masalah.

\section{F. Teknik Analisis Data Penelitian}

Teknik pengolahan data dilakukan melalui analisis tulisan artikel dan pengolahan hasil analisis tulisan artikel. Kegiatan menganalisis karangan dilakukan untuk memberikan gambaran keberhasilan mahasiswa dalam menulis artikel.

\section{G. Pengolahan Hasil Analisis Tulisan Artikel}

Pengolahan hasil analisis tulisan artikel merupakan salah satu langkah yang sangat penting dalam kegiatan penelitian untuk mengimplikasi data dalam bentuk simpulan. Nilai tulisan artikel diolah secara statistik dengan menggunakan program ecxel dan SPSS 18. Langkah-langkah pengolahan data hasil penelitian adalah sebagai berikut.

1. Untuk lebih mempermudah dalam memahami data yang diperoleh dari hasil penelitian, maka sebelum Dianalisis data tersebut dideskripsikan terlebih dahulu. pendeskripsian data ini berguna untuk meringkas dan menjelaskan data yang diperoleh melalui instrumen penelitian. Ukuran-ukuran statistik yang digunakan dalam pendeskripsian data yaitu:

a. Data yang akan dianalisis untuk menguji hipotesis penelitian Ukuran tendensi senteral berupa mean (rata-rata), median, modus, dan jumlah data.

b. Ukuran penyebaran data berupa varians, standar deviasi, data terkecil, data terbesar, dan rentang.

c. Daftar frekuensi dan daftar distribusi frekuensi. 
2. Data yang akan dianalisis untuk menguji hipotesis penelitian adalah data nilai hasil karangan. Teknik analisis data yang digunakan untuk menguji hipotesis penelitian adalah sebagai berikut.

a. Data diuji normalitasnya dengan menggunakan Chi-Kuadrat. Rumus yang digunakan yaitu: $(x)^{n}=$ $\sum_{i=1}^{k} \frac{\left(\mathrm{o}_{\mathrm{i}}-\mathrm{E}_{\mathrm{I}}\right)^{2}}{\mathrm{E}_{\mathrm{i}}}$

Keterangan:

$k=$ banyaknya kelas interval dari daftar distribusi frekuensi

$o_{i}=$ frekuensi hasil pengamatan

$E_{i}=$ frekuensi teoretis yang diharapkan

Hipotesis yang diujikan adalah:

$H_{0}$ : data berasal dari distribusi normal

$H_{1}$ : data tidak berasal dari distribusi normal

Kriteria pengujiannya yaitu:

- Jika $x^{2}$ hitung $<x_{(1-a)(k-1)}^{2}$ maka terima $H_{0}$

- Jika $x^{2}$ hitung $\geq x_{(1-a)(k-1)}^{2}$ maka tolak $H_{0}$

Sudjana (1996:393)

b. Data uji homogenitasnya dengan menggunakan uji $\mathrm{F}$

Untuk menguji homogenitas varians dengan menggunakan statistik uji $\mathrm{F}$, rumus yang digunakan yaitu: $F=\frac{\text { varians terbesar }}{\text { varians ter }}$

hipotesis yang diujikan adalah:

$H_{0}: \quad \sigma_{1}^{2}=D_{1}^{2}$, varians populasi adalah identik (varians kelas eksperimen dan kelas kontrol adalah sama).

$H_{0}: \quad \sigma_{1}^{2} \neq \sigma_{1}^{2}$, varians populasi adalah tidak identik (varians kelas eksperimen dan kelas kontrol adalah tidak sama).
Kriteria pengujiannya yaitu:

- Jika F hitung $<F_{(1 / 2 a)}(d k 1, d k 2)$ maka terima $H_{0}$

- Jika F hitung $\geq F_{(1 / 2 a)(d k 1, d k 2)}$ maka terima $H_{0}$

Sudjana (1996:250)

c. Data uji kesamaan dua rata-ratanya dengan t-test untuk dua sampel bebas jika data berdistribusi normal dengan uji U-Mann Whitney jika data tidak berdistribusi normal.

\section{HASIL DAN PEMBAHASAN A. Gambaran Umum Objek Literatur}

Objek kajian dalam penelitian ini adalah tulisan berupa artikel. Dalam hal ini, artikel yang dimaksud berupa hasil pemaparan penulis mengenai suatu topik yang disertai argumen atau pandangan serta sikap penulis. Hal ini dilandasi oleh pernyataan Soeseno dalam Priyanto (2012:14) bahwa artikel merupakan tulisan tentang suatu masalah berikut pendapat dan pendirian penulisnya tentang masalah tersebut.

Selain apa yang telah diuraikan di atas, yang paling penting mengenai objek penelitian ini adalah bahwa tulisan yang diteliti merupakan tulisan yang bersifat nonfiksi. Hal tersebut mengacu pada pernyataan Pranata dalam Andriyansah (2014:5-6) bahwa artikel merupakan karya tulis atau karangan, karangan nonfiksi, karangan tak tentu panjangnya karangan yang bertujuan untuk meyakinkan, mendidik, atau menghibur. Sebagai objek kajian, tulisan artikel yang dinilai atau diteliti adalah tulisan yang dibuat oleh subjek penelitian, yakni mahasiswa STKIP Siliwangi Bandung, khususnya angkatan 2014. 


\section{B. Kemampuan Mahasiswa Menulis Artikel Sebelum dan Sesudah meng- gunakan strategi active learning tipe konrak belajar}

Kemampuan awal dan akhir menulis mahasiswa semester 3 Program Studi Bahasa dan Sastra Indonesia diketahui dari hasil pretesdan postes. Data tersebut dianalisis berdasarkan aspek kemampuan menulis artikel yang meliputi keoriginalan, keaktualan, dan tulisan. Selanjutnya data dideskripsikan berdasarkan aspek kemampuan menulis artikel. Data yang dikutip dalam analisis berupa kalimat yang sesuai dengan kriteria skor pada tiap aspek. Hasil tulisan mahasiswa dikelompokkan ke dalam empat kategori yaitu sangat baik, baik, sedang dan kurang. Nilai mahasiswa yang dikategorikan $s a-$ ngat baik yaitu antara nilai 86 sampai dengan 100, dikategorikan baik, antara 76 sampai dengan 85, dan kategori cukup antara 56 sampai dengan 75, adapun di bawah 10 sampai dengan 55 kriterianya kurang (Nurgiantoro, 2012: 253).

\section{Analisis Data Hasil Pretes dan Postes}

Analisis penilaian pembelajaran dapat diperoleh dari hasil perhitungan nilai pretes dan postes. Perolehan nilai pretes dan postes tersebut dilakuakan dalam dua tahap. Tahap pertama, yaitu penilaian yang dilakukan di awal sebelum kegitan pembelajaran dilakukan. Tahap kedua, yaitu penilaian yang dilakukan di akhir atau disebut postes. Sampel yang digunakan untuk melakukan penilaian yaitu mahasiswa angkatan 2014 kelas A1 STKIP Siliwangi Bandung.

Berdasarkan hasil pretes dapat diketahui nilai terendah sampai tertinggi yang diperoleh mahasiswa. Nilai teren- dah yaitu 0 dan nilai tertinggi 80 . Adapun rincian sebagai berikut: 1orang memperoleh nilai 0 , sebanyak 2 orang memperoleh nilai 20, sebanyak 3 orang memperoleh nilai 30, sebanyak 9 orang memperoleh nilai 40, sebanyak 9 orang memperoleh nilai 50. Sebanyak 7 memperoleh nilai 60 . Sebanyak 4 orang memperoleh nilai 70 sedangkan hasil nilai postes, nilai terendah yaitu 40 dan nilai tertinggi 80 . Adapun rincian sebagai berikut: sebanyak 4 orang memperoleh nilai 40 , sebanyak 11 orang memperoleh nilai 50 . Sebanyak 13 memperoleh nilai 60. Sebanyak 6 orang memperoleh nilai 70, dan 3 orang memperoleh nilai 8 .

Dilihat dari data tersebut, maka hasil perhitungan nilai pretes dan nilai postes menggunakan tabel distribusi frekuensi dapat diketahui selesih rata-rata antara nilai pretes dan postes sebagai berikut.

$$
\begin{aligned}
\text { Selisih mean } & =\mathbf{M y}-\mathbf{M x} \\
& =61,4-46,8 \\
& =14,6
\end{aligned}
$$

Berdasarkan perhitungan selisih rata-rata nilai pretes dan postes di atas, diketahui nilai rata-rata postes lebih besar daripada nilai pretes yakni 61,4>46,8 dengan selisih sebesar 14,6. Hal ini menunjukan adanya kemajuan peningka$\tan$ hasil belajar mahasiswa.

\section{Menguji Signifikansi Koefisien t}

Pengelolahan data dan hasil penelitian nilai pretes dan postes menggunakan rumus $t_{\text {tes }}$ memiliki ketentuan jika $\mathrm{t}$ hitung > t tabel maka hipotesis diterima apabila $t$ hitung $<\mathrm{t}$ table maka hipotesis ditolak. Diketahui nilai rata-rata pretes 50 , nilai rata-rata postes 56,2 , selisih antara nilai postes dan nilai postes sebesar 5,5 serta nilai gain sebesar 295. Adapun perhitungan koefisien dan uji t berdasarkan nilai rata-rata pretes, nilai 
rata-rata postes, dan nilai gain sebagai berikut.

$$
\begin{aligned}
& \text { Uji t } \\
& \text { d.b = N - } 1 \\
& =35-1 \\
& =34
\end{aligned}
$$

Taraf signifikansi (a) 5\% $=0,05$

Taraf kepercayaan $95 \%=0,95$

d. $b=34$

$\mathrm{t}$ tabel $=\mathrm{t}(1-1 / 2 \mathrm{a})(\mathrm{d} . \mathrm{b})$

$=\mathrm{t}(1-1 / 20,05)(34)$

$=\mathrm{t}(1-0,025)(34)$

$=\mathrm{t}(1-0,975)(34)$

$=2,04$

Dilihat dari hasil perhitunagan kuadrat deviasi, koefisien, uji t, dan analisis yang telah dilakukan diperoleh hasil derajat kebebasan sebesar 34 dengan tingkat kepercayaan $95 \%$ ternyata $t_{\text {hitung }}{ }^{-}$ $>t_{\text {tabel }}$, yakni $2,75>2,04$. Artinya terdapat perbedaan yang signifikan antara pretes dan postes pada mahasiswa semester 3 angkatan 2014 dalam pembelajaran menulis artikel dengan menggunakan strategi active learning tipe kontrak belajar.

\section{E. Analisis Pengamatan Observasi Pelak-sanaan Pembelajaran Menulis Artikel dengan Strategi Active Learning Tipe Kontrak Belajar}

Berdasarkan hasil observasi yang dilakukan observer terhadap pembelajaran menulis pembelajaran menulis artikel dengan strategi active learning tipe kontrak belajar, kegiatan pembelajaran berlangsung sebagai berikut.

1. Pendahuluan

Tahap ini adalah tahap dosen memulai pembelajaran. Sebelum memulai, dosen mengucapkan salam, menge- cek kehadiran mahasiswa dan menanyakan kabar atau keadaan mahasiswa pada saat itu. Menanyakan siapa yang tidak hadir dan apa alasan ketidakhadiran-nya. dosen berupaya mengkondisikan kelas dengan menyebarkan pandangan ke seluruh ruangan dan meminta mahasiswa supaya lebih tenang karena pembelajarn inti akan segera dimulai. Observer yang duduk di bagian belakang kelas mengamati dosen menyampaikan materi mata kuliah yang akan dipelajari.

Hasil pengamatan observer menunjukkan bawa dosen talah menyampaikan pembelajaran dan mahasiswa menaruh respon positif terhadap pembelajaran yang disampaikan dosen. Setelah tujuan mata kuliah disampaikan, dosen menyampaikan inti permasalahan yaitu penggunaan strategi active learning tipe kontrak belajar. Ketika dosen mengutarakan hal tersebut sebagian besar mahasiswa nampak tertarik, senang dan penasaran.

2. Tahap Inti

Berdasarkan pengamatan pada tahap ini, mahasiswa diperkenalkan terlebih dahulu tentang menulis, artikel, kriteria menulis artikel, dan langkah-langkah menulis artikel lewat tayangan power point. Kemudian setelah selesai, mahasiswa membentuk beberapa kelompok dan dosen meminta mereka secara berkelompok untuk menulis artikel berdasarkan tema yang telah disepakati. Setelah itu dosen bersama sama dengan mahasiswa mencari tahu hal-hal apa saja yang ditulis menjadi sembuah artikelt. Dari pengamatan peneliti mahasiswa sebagaian sudah mengetahuinya. Terbukti mahasiswa mampu menulis artikel dengan rinci, jelas, dan tepat. Selanjutnya dosen menjelaskan ulang pengertian menulis artikel, kriteria menulis artikel, dan langkah- 
langkah menulis artikel dalam tiap pertemuannya.

Bila diamati secara menyeluruh setiap pertemuan dalam pembelajaran menulis artikel dengsn strategi active learning tipe kontrak belajar, antara dosen dan mahasiswa sudah terjalin komunikasi dengan baik. Diskusi sering berlangsung seru namun beretika. Mahasiswa tampak bersemangat untuk mengemukakan pendapatnya apabila ada hal yang ditanyakan oleh dosen mengenai pembelajaran menulis artikel. Pada tahap ini juga, mahasiswa diminta untuk berlatih menulis artikel minimal dua paragraf, siswa melakukannya dengan antusias dan menyelesaikan pekerjaan sesuai dengan waktu yang ditentukan.

3. Penutup

Pada tahap ini, dosen melakukan evaluasi terhadap seluruh rangkaian pembelajaran menulis artikel dengan strategi strategi active learning tipe kontrak belajar mahasiswa diajak untuk menyimpulan materi perkuliahan yang telah dilaksanakan. Mahasiswa dan dosen mendiskusikan tentang menulis artikel, karakteristik, dan tulisan. Tahap akhir dari keseluruhan pembelajaran menulis artikel dengan strategi active learning tipe kontrak belajar, siswa ditugaskan untuk menulis artikel.

\section{F. Pembahasan Hasil Penelitian}

Menulis merupakan keterampilan berbahasa yang produktif dan sangat penting dalam hal ini khususnya bagi mahasiswa karena dapat mengembangkan dan meningkatkan taraf berpikir seseorang. Salah satu kegiatan menulis yang meningkatkan taraf berpikir yaitu menulis artikel. Soeseno dalam Priyanto (2012:14) mengungkapkan bahwa artikel merupakan tulisan tentang suatu masalah berikut pendapat dan pendirian penulisnya tentang masalah tersebut. Oleh karena itu kegiatan belajar khususnya menulis harus menciptakan suasana yang menyenangkan dan memberikan kesan mendalam pada mahasiswa (peserta didik), seperti yang diungkapkan oleh Silberman (2011:207) bahwa belajar yang timbul dari keinginan sendiri acapkali lebih mendalam dan lebih permanen ketimmbang belajar yang diarahkan oleh Dosen. Dengan demikian seorang pengajar harus memilih model dan strategi yang tepat dalam kegiatan belajar. Active learning sendiri merupakan kegiatan belajar aktif yang bisa membuahkan hasil belajar yang langgeng (Silberman, 2011:9). Strategi active learning tipe kontrak belajar merupakan strategi pembelajaran yang aktif dengan memberikan kebebasan kepada mahasiswa (peserta didik) dalam menggunakan otak, mengkaji gagasan, memecahkan masalah, dan menerapkan apa yang mereka pelajari.

Berdasarkan hasil pengamatan pelaksanaan pembelajaran menulis artikel dengan strategi active learning tipe kontrak belajar dapat menumbuhkan sikap semangat, mahasiswa tampak tertarik, senang, dan antusias. Terbukti mahasiswa mampu menulis artikel dengan rinci, jelas, dan tepat. Mahasiswa tampak bersemangat untuk mengemukakan pendapatnya apabila ada hal yang ditanyakan oleh dosen mengenai pembelajaran menulis artikel. Hal ini juga terlihat dari perolehan hasil selisih kemampuan mahasiswa menulis artikel sebelum dan sesudah menggunakan strategi active learning tipe kontrak belajar dengan nilai rata-rata postes lebih besar daripada nilai pretes yakni 61,4 > 46,8 dengan selisih sebesar 14,6 artinya terdapat peningkatan 
terhadap kemampuan menulis artikel mahasiswa.

\section{KESIMPULAN}

Hasil penelitian dan pembahasan pada bab sebelumnya menunjukan bahwa secara umum dapat disimpulkan pembelajaran menulis artikel dengan menggunakan strategi active learning tipe kontrak belajar dapat meningkatkan kemampuan menulis artikel mahasiswa STKIP Siliwangi Bandung. Menulis artikel merupakan keterampilan menulis yang idea tahu gagasannya dituangkan berdasarkan pendapat atau opini mengenai suatu fenomena. Secara khusus beberapa hal yang dapat disimpulkan sesuai dengan rumusan penelitian sebagai berikut.

1. Berdasarkan hasil penelitian pada kemampuan awal (pretes) mahasiswa semester 3 sebelum diterapkan pembelajaran menulis artikel dengan menggunakan strategi active learning tipe kontrak belajar, kemampuan yang diperoleh adalah 50. Setelah diberikan perlakukan akhir (postes) yang diperoleh mahasiswa adalah 56,2 .

2. Berdasarkan pengolahan data pada proses pembelajaran melalui pembelajaran menulis artikel dengan menggunakan strategi active learning tipe kontrak belajar diketahui bahwa pembelajaran menulis artikel lebih efektif, menyenangkan, sampel dapat mengetahui langkah-langkah menulis artikel dengan baik, dan dapat meningkatkan keterampilan menulis khususnya menulis artikel.

3. Terdapat perbedaan yang signifikan pada kemampuan menulis artikel. Hal ini ditujukan dari hasil perhitungan analisis data penelitian. Berdasarkan hasil uji perbedaan rata-rata pada tes awal dan akhir diketahui tingkat kepercayaan $95 \%$ ternyata $t_{\text {hitung }}$ $>t_{\text {tabel }}$, yakni $2,75>2,04$.

\section{DAFTAR PUSTAKA}

Alwasilah \& Senny Suzanna A. (2005). Pokoknya menulis. Bandung: Kiblat.

As. Haris, Sumadiria. 2015. Jurnalistik indonesia, menulis berita dan feature panduan praktis jurnalistik profesional. Bandung: PT. Remaja Rosdakarya.

Cahyani, I. (2011). Pembelajaran kontekstual untuk meningkatkan kemampuan menulis eksposisi. Jurnal Artikulasi Vol. 10, No. 2, November 2011, halaman 169-177.

H. Daryanto. 2005. Evaluasi pendidikan. Jakarta: Rineka Cipta.

Hughey, B. jane. Et. all. (1983). Teaching esl composition: principles and techniques. Cambridge: Newbury House Publishers Adivition of Harper \& Row, Publishers, Inc.

Nurudin. (2010). Dasar-dasar penulisan. Malang: UMM Press

Sagala. 2011. Konsep dan materi pembelajaran. Bandung: ALFABETA.

Silberman, Melvin. Active learning 101 cara belajar siswa aktif. Bandung: Nusa Media.

Sumiyati \& Asra M. 2009. Metode pembelajaran. Jakarta: Wacana Prima.

Suparno dan Muhammad Yunus. (2006). Keterampilan dasar menulis. Jakarta: Universitas Terbuka.

Suryosubroto. 1990. Tatalaksana kurikulum. Jakarta: Rineka Cipta.

Oemar, Hamalik. 1995. Proses pembelajaran. Jakarta 